\title{
CHALLENGES WITH THE IMPLEMENTATION OF THE ADMISSION POLICY FOR GRADES R AND 1 IN THE MOTHEO DISTRICT IN THE FREE STATE PROVINCE OF SOUTH AFRICA
}

\author{
Jaysveree M Louw \\ Department of Educational and Professional Studies, Central University of Technology (CUT), \\ Bloemfontein (South Africa)
}

\begin{abstract}
At the beginning of every year thousands of learners report for Grade $\mathrm{R}$ and Grade 1 across schools in South Africa. Unfortunately, many learners are refused admission to these grades when parents apply. The national policy that guides and governs admission of learners to public schools is the South African Schools Act (SASA) 84 of 1996. This policy stipulates that the admission age of a learner to a public or independent school for Grade $\mathrm{R}$ is age four, turning five by 30 June in the year of admission. For a learner to be admitted to Grade 1, the learner has to be five, turning six by 30 June in the year of admission (SASA 1996 Section 5a-6; Ramadiro and Vally 2005:1). But SASA (1996: Section 3(1) also states that attendance is compulsory in the year in which a learner turns seven. According to the National Education Policy Act (NEPA) 27 of 1996 and SASA (1996: Section 5) the Admission Policy of a public school is determined by the School Governing Body (SGB). However, according to the findings of the research there is no uniformity and consistency in schools as far as admission to Grades R and 1 is concerned. In addition, the study reveals that many parents are unaware of the age requirements for Grades $\mathrm{R}$ and 1 . Although SASA does stipulate the admission age to Grade R and Grade 1, it also states that schools, in the form of the SGB, can determine their own Admission Policy. Hence some schools admit learners according to SASA, while others ignore the requirements stipulated in SASA and determine their own Admission Policies. The study aims to determine what the challenges are with the implementation of the policy. A qualitative research method in the form of interviews was conducted to collect data from teachers, parents, SGBs, school principals and departmental officials. Based on the findings recommendations were made, one of which is that there should be uniformity amongst schools as far as policy implementation is concerned. The theoretical framework that guides this study is document phenomenology.
\end{abstract}

Keywords: Admission, policies, grade $R$, grade 1, admission age.

\section{Introduction}

There are very few aspects of society that are not impacted by law, including education (Meier and Marais 2018:61). Some of the laws that govern education in South Africa include the South African Constitution 108 of 1996, NEPA 27 of 1996, the Education White Paper 5 on Early Childhood Education (ECE), SASA 84 of 1996 and the Curriculum and Assessment Policy Statement (CAPS) of 2011. The two policies that regulate admission to Grades $\mathrm{R}$ and 1 , and that will mainly inform this research, are SASA 84 of 1996 and NEPA 27 of 1996. The Constitution is the supreme law of South Africa. It stipulates that 'everyone has the right to a basic education, which the state, through reasonable measures, must make progressively available and accessible' (South African Constitution of 1996, Section 29). Early Childhood Education (from birth to about nine years, or from birth to the end of Grade 3) is particularly crucial because it lays the foundation for the child's further and future education (Department of Education 2001a: 3). Primary school education starts with the application process for admission to a school. In many cases, especially in urban areas, parents can exercise their choice of schools (Miller 2018: vi and 30). After parents apply, they are typically given a waiting period, after which they will be informed of the outcome of the application. Usually there are three outcomes: the learner is accepted at the school, the application is rejected, or sometimes learners are placed on a waiting list. 
The primary research question this paper seeks to address is: Why are there challenges with regards to the implementation of the Admission Policy to Grades R and 1? I will address this question by attempting to answer the following sub question:

- What is the age of admission to Grades $\mathrm{R}$ and 1 , according to SASA?

\section{Aim of the study}

The aim of this qualitative study was to determine the challenges that schools experience with the implementation of the Admission Policy to Grades R and 1, and why they experience these challenges.

\section{Problem statement}

SASA stipulates that learners should be admitted to Grade R when they are four years old, turning five by 30 June in the year of admission. Grade R (also called the Reception Year) is the year of schooling before Grade 1 (Janse van Rensburg 2015:1). For admission to Grade 1, learners must be five years old, turning six by 30 June in the year of admission (SASA 1996 B-6 and B-19). But SASA also has a clause that states that 'subject to this Act, and any applicable provincial law, every parent must cause every learner for whom he or she is responsible to attend a school from the first day of the year in which such learner reaches the age of seven years until the last school day of the year in which such learner reaches the age of 15 years or the ninth grade, whichever occurs first'. The assumption is that when a child is seven years old, he or she is compelled to attend school, presumably Grade 1. But a child can and should be admitted to Grade $\mathrm{R}$ at the age of four, and to Grade 1 at the age of five. However, analysis of the results indicates that $70 \%$ of parents claim that some schools did not want to admit their children, even though they met the age requirements (cf. Janse van Rensburg 2015:1). Some schools informed parents that for admission to Grade $\mathrm{R}$, the child has to be five, turning six anytime during the year of admission, not necessarily by 30 June. For admission to Grade 1, parents were informed their child has to be six, turning seven in the year of admission, not necessarily by 30 June in the year of admission, as stipulated by SASA. Some schools indicated that, in their experience, four-year old learners are too young to be in Grade R, and that five-year olds are too young to be in Grade 1. The result is that some children that are supposed to be in Grade $\mathrm{R}$ are placed in pre-Grade $\mathrm{R}$, and some children that should rightfully be in Grade 1 are placed in Grade R. Subsequently these learners are 'one year behind' with their schooling. What further complicates the problem of learner admission, is the fact that schools can determine their own admission requirements for Grades R and 1. SASA (1996: Section 5) allows SGBs to determine the Admission Policy of schools, but this determination must be subject to the Act. Do schools then correctly implement the admission policy if they place Grade R and Grade 1 learners a year behind? Most of the schools that participated in the research opt to admit learners to Grade R only in the year they turn six, and to Grade 1 only in the year they turn seven. The most common reason for this choice is that teachers feel learners turning five in Grade R are too young and not school ready, and learners turning six in Grade 1 are too young for Grade 1 (Bruwer, Hartell and Steyn 2014:1; Janse van Rensburg 2015:1). SASA also stipulates that the SGB of a public school, or any other person, may not administer any tests related to the admission of a learner to a public school (SASA 1996: Section 5). This implies that school readiness tests should not be used to determine whether or not children are ready for school, regardless of the child's age. The policy does, however state that under exceptional cases, parents can apply for admission for learners who are at a lower age than the admission age (for Grades R and 1), if such an admission is in the child's best interest (SASA 1996: Section 5c).

\section{The importance of early childhood education}

Early childhood education refers to a comprehensive approach to policies and programmes for children from birth to nine years of age with the active participation of their parents and caregivers (Department of Education 2001; Denham, Bassett and Zinsser 2012). In South Africa, Grade R forms part of the Foundation Phase and can be provided by public or independent schools, community-based EDC sites and independent EDC sites attached to primary schools (Naude and Meier 2019: 58; SASA 1996: Section 5; Department of Basic Education 2001). It provides a key foundational year where the gap between home and formal schooling is bridged (Meier and Ndou 2021:82). Grade R is however, more informal than Grade 1, and the focus is on learning through play (or play-based learning), exploration, incidental and spontaneous learning (Department of Education 2001: 3.2-3.2.9; 5; Naude and Meier 2019:58). In countries such as South Korea and the USA children start formal primary school (referred to as elementary school) at around age five (www.asmilan.org:2021; Nuffic 2015:6). This is also the trend in 
European countries such as Austria, Bulgaria and the Netherlands (Depp: 2020). In Zimbabwe primary education starts from age six (www.scholaro.com: 2021). In South Africa, policy recommendations were made in 1997 to make Grade R compulsory for admission to Grade 1, and its provision was to be phased over a five-year period (Department of Education 2001). The plan was to make it compulsory from 2019. But the question is: is Grade R currently compulsory? The Constitution of South Africa (Act 108 0f 1996: Section 29) states that every child has a right to basic and further education. It also stipulates that the state must, through reasonable measures, make education available and accessible to children. According to SASA, a public school must admit learners and serve their educational requirements without unfair discrimination in any way (SASA 1996: Section 5). Some schools unfairly discriminate against learners in terms of the requirement age for admission to Grades $\mathrm{R}$ and 1.

\section{Research methods}

The theoretical framework that underpins the study is document analysis, also referred to as document phenomenology. It is an analytical framework in which the researcher can review or evaluate documents. It is often used in combination with other qualitative research methods as a means of triangulation - the combination of methodologies in the study of the same phenomenon (Bowen 2009:27). After reviewing and analysing the Admission Policy, I conducted interviews with the participants. Qualitative, exploratory research was conducted to collect data. Data collection methods in the form of structured, face-to-face interviews were employed. Okeke and Van Wyk (2017:209) state that qualitative research is concerned with understanding how a particular individual, or groups of individuals think and the meaning they attach to their thinking. The rationale for conducting interviews to collect data is because interviews allowed me to understand how and what the participants think about the topic, and subsequently the questions they were asked that stemmed from the topic. Purposeful sampling was used to identify and select the population (participants), which consisted of parents, teachers, principals, SGB members and departmental officials. Unstructured, focus group interviews were conducted with 15 teachers from five primary schools (three teachers from each school), and with 30 parents who had children who were either going to start Grade R or Grade 1. Individual, in-depth, face-to-face interviews were conducted with two officials from the Department of Basic Education, and with five principals. The questions posed to the parents were generally to determine whether they are aware of the Admission Policy and what it stipulates regarding Grade $\mathrm{R}$ and Grade 1 admission. The rest of the participants were asked questions related to how the Admission Policy is implemented.

\section{Analysis and findings}

The study found that $70 \%$ of parents are unaware of the requirement age for admission, as stipulated by law. $82 \%$ of parents are not aware of the South African Schools Act. Some are aware that there is such an act but are unaware of the content. Therefore, if the schools informed parents their children were too young for admission, either for Grade R or Grade 1, some parents accepted the outcome without question. Also, many parents are unaware that, should their children be refused admission to a public school, they can appeal against the decision to the Member of the Executive Council (MEC) of education (SASA 1996: Section 5 (9)). From the findings it is evident that some schools do not implement the admission policy as they should because the policy is confusing. Thus, some schools adhere to the requirements as stipulated in SASA, some do not. The schools that do not, are not acting in accordance with SASA. Subsequently, some children are placed in Grade R when they are supposed to be in Grade 1. Some children are referred by schools to pre-Grade R, when they are actually supposed to start Grade R. There is no question that chronological age alone does not determine whether a child is ready for Grade $\mathrm{R}$ or Grade 1. It is quite possible that some children are in the correct age group to be admitted to Grade R for instance, but schools may feel that the child is not school ready or that the child is not mature enough. Some teachers stated that "many five year olds are not emotionally mature to be placed in Grade 1, and that these children should rather be placed in Grade R". One teacher made the example of a five year old Grade 1 learner who cried to be with her older brother, who was at the same. There thus seems to be certain instances where schools can motivate why some children have to be 'held back', but this should be the exception rather than the rule. In cases where teachers feel that children are too young to be admitted to Grades $\mathrm{R}$ and 1 (even though the children are, by law, in the correct age group), teachers can at best only advise the parents to put their children in a lower grade. Ultimately the final decision must be made by the parents, not by the schools. The Department officials admitted that they are aware of the non-implementation of this policy. According to both, learners should be admitted to Grade $\mathrm{R}$ when they are four and should be in Grade 1 when they are five. When asked what the Department does to rectify the problem, the officials explained that they undertake school visits yearly to 
inform schools about the correct implementation of the policy. One official claimed that "schools just do what they want and many schools ignore, or do not correctly implement policies." The official explained that the admission ages to Grades $\mathrm{R}$ and 1 is also sometimes published in local newspapers, together with dates of when parents can apply.

\section{Recommendations}

According to Bowen (2009) documents can be a rich source of data, but researchers should look at documents with a critical eye and be cautious in using documents in their studies. The researcher should consider the original purpose of the document - the reason it was produced. The Admission Policy for Grades R and 1 was formulated to guide schools with the admission of these grades. But the research reveals that some schools do not implement the policy the way they should - there is thus a gap between policy on paper and policy in practice. There seems to be gaps and inconsistencies between the policy and how it is applied in practice. Based on this non-implementation it is recommended that all schools should admit and enrol learners according to the age requirement stipulated in the Admission Policy (unless there are valid reasons for non-implementation). This was clearly stated by the Department officials during interviews. The South African Schools Act is a national policy, and there should thus be uniformity as far as its implementation is concerned. The problem is that many schools do not implement the policy because they feel that four year old learners are not ready for Grade R, and five year olds are still too young for Grade 1. Schools reject these 'young' learners because they feel it is in the learners' best interest. What also makes implementation difficult is the fact that the policy states that the governing body of a public school must determine the admission policy of that school. This then means that schools can determine their own admission policy, although the age requirements are stipulated in SASA. The schools and the Department of Basic Education need to operate in sync, and the Department of Basic Education has to ensure that schools implement policies, whether it be the Admission Policy or any other policies that address education issues.

\section{Summary and conclusion}

The paper aimed to highlight the challenges experienced with the implementation of the Admission Policy for Grades R and 1 in schools in South Africa. Document analysis was employed, which was followed by interviews. Data collected reveal that many schools do not implement the Admission Policy as they should. What complicates the matter is the fact that, although the policy gives the admission ages for Grades R and 1, the same policy stipulates that the governing bodies of schools can determine their own admission policies. The researcher critically reviewed the policy and found that there is gap or discrepancy in the policy - this is a possible reason why the policy is not correctly implemented. The Admission Policy was designed to provide for a uniform policy for admission to Grades $\mathrm{R}$ and 1 , but there seems to be no uniformity.

\section{References}

Bowen, A. 2009. Document analysis as a Qualitative Research Method. Qualitative Research Journal. Volume 9. No 2: 27-40.

Bruwer, M., Hartell, C. \& Steyn. Inclusive education and insufficient school readiness in Grade 1: Policy versus Practice. South African Journal of Childhood Education. Volume 4. No. 2: 1-12.

Denham, A., Bassett, H.D. \& Zinsser, K. 2012. Early Childhood Teachers as Socializers of Young Children's Emotional Competence. Early Childhood Education Journal. Published Online.

Department of Education. 1996. National Education Policy Act 27 of 1996. Pretoria.

Department of Education. 1996. South African Schools Act No. 84 of 1996. Pretoria.

Department of Education. 2001. Education White Paper on Early Childhood Education. Pretoria.

DEPP. 2020. Education in Europe: key figures. $3^{\text {rd }}$ Edition.

Janse van Rensburg, O. The school readiness performance of a group of Grade R learners in Primary Schools in the Gauteng Province of South Africa. South African Journal of Childhood Education. Volume 5. No. 1: 1-11.

Meier C., \& Ndou, N. (Eds.). 2021. Teaching in the Foundation Phase: Contemporary strategies, curriculum development and assessment. Pretoria. Van Schaik Publishers. 
Meier, C. \& Marais, P. 2018. (Eds.). Management in Early Childhood Education: A South African perspective. Pretoria. Van Schaik Publishers.

Miller, D.E. 2018. Factors affecting parental choice of schools for Grade 1 learners. M. Ed Thesis. Pretoria. University of Pretoria.

Naude, M. \& Meier, C. (Eds.). 2019. Teaching Foundation Phase Mathematics: A guide for South African students and teachers. Pretoria. Van Schaik Publishers.

Nuffic. 2015. Education system South Korea described and compared with the Dutch system. $1^{\text {st }}$ Edition.

Okeke, C. \& Van Wyk, M. (Eds.). Educational Research: An African approach. Cape Town. Oxford University Press.

Ramadiro, B. \& Vally, S. 2005. (Eds.). Admission Policy: Your Rights. Johannesburg. Wits Education Unit.

South Africa. 1996. The Constitution of the Republic of South Africa. Act 108 of 1996. Pretoria.

www.asmilan.org. Retrieved on 28 April 2021.

www.scholaro.com. Retrieved on 28 April 2021. 